M. J. Lighthill (Royal Aircraft Establishment, Farnborough), the Rt. Hon. Douglas P. T. Jay, M.P., Prof. D. T. Jack (University of Durham), Prof. W. T. Astbury (University of Leeds), Prof. R. Meredith (Royal College of Science and Technology, Glasgow), Prof. R. Nicholson (Royal College of Art), Prof. Janey Ironside (Royal College of Art) and Sir Walter Puckey (chairman, Automation Consultants and Associates, Ltd., and of Management Selection, Ltd.). Further information can be obtrined from the Golden Jubilee Conference Organizer, Textile Institute, 10 Blackfriars Street, Manchester 3.

\section{Advisory Committee on Scientific Work of the Infestation Control Laboratory}

THE Minister of Agriculture, Fisheries and Food has appointed the following committee to advise and report annually on the programme of experimental and research work of the Infestation Control Laboratory of the Ministry: Prof. J. B. Cragg, professor of zoology in the University of Durham (chairman); Mr. H. R. Hewer, reader in zoology, Imperial College of Science and Technology; Dr. T. Moran, director of research for the Research Association of British Flour Millers, St. Albans, Herts; Mr. F. Rayns, director of the Norfolk Agricultural Station, Sprowston, Norwich; Prof. H. G. Sanders, chief scientific adviser (agriculture), Ministry of Agriculture, Fisheries and Food; Prof. V. C. Wynne-Edwards, professor of natural history, University of Aberdeen. The secretary of the Committee is Miss Y. Larthe. Assessors to the Committee are: Mr. A. S. Fortune, chief inspector, Department of Agriculture for Scotland; Dr. R. A. E. Galley, director of the Tropical Products Institute, Department of Scientific and Industrial Research; Mr. G. V. B. Herford, director of the Pest Infestation Laboratory, Slough, Bucks ; Mr. G. G. Samuel, Agricultural Research Council; Dr. E. B. Worthington, deputy director-general (scientific), Nature Conservancy.

\section{Announcements}

H.M. THE QUEEN has conferred the Order of Merit on Sir Cyril Hinshelwood, Dr. Lee's professor of chemistry in the University of Oxford and president of the Royal Society. Lord Radnor, chairman of the Forestry Commission sinee 1952, has been appointed a knight of the Order of the Garter.

Dr. Richard O. Roblin, vice-president for research and development of the American Cyanamid Company, who is known for his work on sulphadiazine and sulphamerazine, has been elected president and director of the Cyanamid European Research Institute in Geneva; Dr. Mario Scalera, assistant to the general manager of the Central Research Division of Cyanamid, has been elected a vice-president of the Institute. The Institute, which last year acquired eight and a half acres of land for its laboratories in Geneva's Cologny section, will be devoted to longrange, basic research in the chemical and related fields.

THE Trustees of the Rockefeller Foundation have authorized a grant of 30,000 dollars to the Marine Biological Association of the United Kingdom for the purchase of research equipment for use in the Plymouth laboratory.

The Latin American school of physies is to be held this year at the Centro Brasileiro de Pesquisas Físicas, under the auspices of Conselho Nacional de Pesquisas do Brasil, Academia Brasileira de Ciências,
Campanha de Aperfeiçoamento de Pessoal de Nível Superior, Pan American Union and Unesco, during June 27-August 7. Further information can be obtained from J. Leite Lopes, Centro Brasileiro de Pesquisas Físicas, Av. Wenceslau Braz, 71 Rio de Janeiro, Brazil.

THE thirtieth annual report of the University Research Committee, University of Birmingham, gives a summary of departmental research progress during the academic year 1958-59. Lists of papers published during the year and of titles of those approved for higher degrees during the period are included in each departmental report, arranged alphabetically by authors (pp. 123. Birmingham: The University, 1960). A selected list of general works and further writings by members of the University staff is appended, arranged under faculties.

THE International Atomic Energy Agency is issuing a world list of institutions concerned with atomic energy (Gen./Pub. No. 3). The list is being issued at irregular intervals as a series of publications ; each publication covering a Mernber State of the Agency. The list is intended to facilitate the exchange of information on nuclear energy between scientists, engineers, research workers and administrators in Member States. Copies can be obtained from the Scientific and Technical Information Division, International Atomic Energy Agency, Kärntner Ring, Vienna.

An international conference on Powder Metallurgy is to be held at the Hotel Beltmore, New York City, during June 13-15. Further information can be obtained from Mr. Kempton H. Roll, Metal Powder Industries Federation, 60 East 42nd Street, New York 19

The sixth Commonwealth Mycological Conference will be held during July 15-22 at the London School of Hygiene and Tropical Medicine, Keppel Street, London, W.C.1. Further information can be obtained from the Director, Commonwealth Mycological Institute, Ferry Lane, Kew, Surrey.

THE thirteenth symposium in biology at the Brookhaven National Laboratory on Protein Struc. ture and Function will be held during June 6-8. Further information can be obtained from Dr. D. E. Koshland, jun., Department of Biology, Brookhaven National Laboratory, Upton, L.I., New York.

THE second annual conference of the British Computer Society, Ltd., is being held during July 4-7 at the Sun Pavilion, Harrogate, Yorkshire. Further information can be obtained from Miss D. E. Pilling, Electronic Computing Laboratory, The University, Leeds 2.

ThIs year the Charité (Faculty of Medicine), Humboldt University, Berlin, celebrates its 250 th anniversary, and functions will be held in conjunction with the 150th anniversary of the University. Further information can be obtained from Dr. Dagobert Müller, secretary of the Committee for Preparations of the 250th anniversary of the Charité, Berlin, N.4. Schumannstrasse 20-21.

ERRATUM. In announcing the award of the $J$. Lawrence Smith Medal of the U.S. Academy of Sciences to Dr. E. J. Öpik (see Nature, April 23, p. 280), it was stated that Dr. Öpik is director of the Armagh Observatory ; he is, in fact, a research associate of the Observatory, the director of which is Dr. E. M. Lindsay. 